Сазонець О. М. [1; ORCID ID: 0000-0001-6521-7815], д.е.н., професор

Никончук В. М. [2; ORCID ID: 0000-0003-4425-4283], K.e.H.

${ }^{1}$ Національний університет водного господарства та природокористування, м. Рівне ${ }^{2}$ ПВНЗ «Міжнародний економіко-гуманітарний університет імені академіка Степана Дем'янчука», м. Рівне

\title{
МЕТОДОЛОГІЯ ДОСЛІДЖЕННЯ ПРОЦЕСІВ ІНТЕЛЕКТУАЛІЗАЦІї В СУЧАСНІЙ ЕКОНОМІЦІ
}

В статті обґрунтовано методологічні засади дослідження інтелектуального капіталу.

Запропоновано методологію дослідження процесів інтелектуалізації в сучасній економіці розглядати як процес інтелектуальної власності, як певний результат щодо наявності інтелектуальних ресурсів; людський капітал, що є основною для формування інновацій та розвитку.

Авторами проведено порівняльний аналіз підходів до оцінки людського капіталу. На основі даних дослідження визначено, що серед наявних підходів, які оцінюють людський капітал на сьогодні можна виділити: підхід за витратами, підхід за доходами та індикативний підхід.

Визначено напрями інтелектуалізації в сучасній економіці. Описано методики, що використовують Всесвітня організація інтелектуальної власності (ВОІВ), Організація економічного співробітництва та розвитку (ОЕСР), Світова організація торгівлі (СОТ), Всесвітній Банк, Всесвітній економічний форум. Запропоновано показники оцінки ефективності національної інституційної системи забезпечення якості освіти та конкурентоспроможності науки з використанням базових індикаторів як основного джерела інформації. Тому новітні методології процесів інтелектуалізації в сучасній економіці хоча і містять достатньо велику кількість показників, проте вони мають досить фрагментарний характер.

Узагальнюючи наявні методології дослідження процесів інтелектуалізації в сучасній економіці, було запропоновано удосконалити підходи оцінки інтелектуального капіталу за рахунок обґрунтування меж застосування існуючих метрик. В межах систематизації наявних наукових опрацювань виявлено, що наявні наукові опрацювання щодо методології дослідження процесів інтелектуалізації в сучасній економіці слід розділяти на дві великі галузі знань - це опрацювання, які стосуються процесів інтелектуальної власності як певного результату щодо наявності 
інтелектуальних ресурсів, а інша галузь знань має справу з людським капіталом, що є основною для формування інновацій та розвитку.

В таких умовах подальше обґрунтування методології процесів інтелектуалізації в національній економіці має значний практичний інтерес.

Ключові слова: методологія наукових досліджень, людський капітал, інтелектуальна власність, інституалізація, базові індикатори.

Постановка проблеми. Одним 3 важливих напрямків сучасних економічних досліджень $€$ аналіз факторів, що впливають на конкурентоспроможність і розвиток національних економік. Так, широкого поширення набула концепція інтелектуального капіталу, яка розглядає людські ресурси, знання й інформацію як ключові фактори економічного розвитку. Посилення уваги вчених до аналізу інтелектуальних ресурсів обумовлено стрімким розвитком сфери науки та інновацій, а також зниженням цінності традиційних факторів виробництва та їх внеску у створення вартості. Беручи до уваги значну нерівномірність економічного розвитку різних національних економічних систем, особливого значення набуває дослідження національних аспектів формування, накопичення та використання інтелектуального капіталу в цілях підвищення ефективності його використання.

Аналіз останніх досліджень і публікацій. У світовій науці можна виділити декілька напрямків дослідження інтелектуального капіталу. Фундаментальні основи використання інформації та знань як факторів виробництва були розроблені у працях К. Маркса, А. Маршалла, П. Хейне, Й. Шумпетера та ін. Серед досліджень питань управління інтелектуальними ресурсами на макроекономічному рівні заслуговують на особливу увагу роботи Дж. Гелбрейта, П. Друкера,
В. С. Єфремова,
В. Л. Іноземцева,
С. М. Клімова,
Е. Тоффлера, Р. Цвильова. В наукових працях цих авторів висвітлено основні проблеми постіндустріального суспільства. Інституціональні аспекти інформації та знань розглядалися К.Менаром, Д.Нортом, Р. Нурєєвим, Р. Коузом, Л. Тевено, О. Фаворо, Ф.А. фон Хайєком, А. Шастітко. Значний внесок у розвиток теоретичних та науковометодичних засад управління інтелектуальним капіталом на рівні підприємства зробили Е. Брукінг, В.Гойло, Б.Б.Леонтьєв, В. С. Пономаренко, Т. Стюарт та ін.

В Україні питаннями теорії та методології інтелектуалізації економіки займаються такі сучасні вчені, як О.Амоша, В. Александрова, Ю. Бажал, Д.Богиня, В. Воронкова, 
А. Гальчинський, В. Геєць, О. Грішнова, О. Кендюхов, Н. Корабльова, В. Корженко, А. Мерзляк, Л. Мельцер, Л. Михайлова, В. Семиноженко, В. Соловйова, Л. Пашко, Л. Штика та інші.

Постановка завдання. Мета статті - обґрунтувати методологічні основи дослідження людського капіталу в контексті інтелектуалізації національної економіки.

Виклад основного матеріалу. В сучасній економічній спільності існує значний рівень єдності думок щодо розуміння важливості знань як джерела економічної конкурентоспроможності, оскільки в даний час все більша частка ВВП знаходиться в категоріях товарів, які практично не мають фізичних проявів. Однак методи та моделі, що використовуються для вимірювання дослідження процесів інтелектуалізації в сучасній економіці їі ефектів, мають досить дискусійних характер, сьогодні досі не існує єдиних стандартів або показників, які могли б бути широко корисними для суспільства знань.

Методологію дослідження процесів інтелектуалізації в сучасній економіці слід розділяти на дві великі галузі знань:

1. Процес інтелектуальної власності як певного результату щодо наявності інтелектуальних ресурсів;

2. Людський капітал, що є основною для формування інновацій та розвитку.

Ці дві галузі наукових концепцій досить погано пов'язані між собою, це добре простежується як у класичних, так і сучасних роботах з інтелектуалізації економіки. Міжнародні організації також розділяють ці категорії в своїх методологічних поглядах, однак погоджуються 3 тим, що людський капітал та інтелектуальна власність $€$ елементами однієї системи.

Галузь знань, що займається проблематикою інтелектуальної власності, характеризується значною кількістю публікацій, проте практичну цінність становлять саме ті метрики, які набули широкого поширення серед міжнародних організацій, відповідальних за міжнародні стосунки в інноваційній сфері. До таких організацій слід віднести наступні.

По-перше, це Всесвітня організація інтелектуальної власності (BOIB), що $€$ однією 315 спеціалізованих установ Організації Об'єднаних Націй (ООН). Відповідно до Конвенції 1967 року ВОІВ була створена для просування та захисту інтелектуальної власності (IB) в усьому світі шляхом співпраці з країнами, а також з міжнародними організаціями. Діяльність ВОІB включає організацію форумів 3 обговорення та формування міжнародних правил і політики в області 
інтелектуальної власності, надання глобальних послуг з реєстрації та захисту інтелектуальної власності у різних країнах, розв'язання транскордонних суперечок в області інтелектуальної власності, допомогу в з'єднанні систем інтелектуальної власності через єдині стандарти та інфраструктуру, а також в якості загальної довідкової бази. На сьогодні ВОІВ управляє 26 міжнародними договорами, які стосуються широкого кола питань, у тому числі визначення метрик щодо інтелектуальної власності та капіталу [08; 23]. По-друге, Організація економічного співробітництва та розвитку (ОЕСР), що є міжурядовою економічною організацією з 37 країнами-членами [19], заснована в 1961 році для стимулювання економічного прогресу та світової торгівлі. Організація економічного співробітництва - це форум країн, які заявляють про свою прихильність демократії та ринковій економіці, надаючи платформу для порівняння політичного досвіду, пошуку відповідей на загальні проблеми, виявлення передового досвіду і координації внутрішньої та міжнародної політики своїх членів. По-третє, це Світова організація торгівлі (СОТ), що займається регулюванням торгівлі товарами, послугами та інтелектуальною власністю між країнами, забезпечуючи основу для переговорів по торговим угодам і процесу врегулювання суперечок, спрямованому на забезпечення дотримання учасниками угод СОТ, які підписані представниками урядів країн-членів [200; 23].

Інша галузь знань, що має справу з людським капіталом і $€$ основною для формування інновацій та розвитку, також нараховує значну кількість публікацій, проте в нашій роботі ми виклали основні напрацювання, які $€$ поширеними саме на практиці. Серед наявних підходів, які оцінюють людський капітал, сьогодні можна виділити: підхід за витратами, підхід за доходами та індикативний підхід [06]. Першим підходом до вимірювання людського капіталу вважається індикативний підхід, він є найбільш простий у застосуванні, разом 3 цим опосередкований за своїм характером.

Індикативний підхід оцінює людський капітал на основі показників обсягу освіти. На сьогодні прихильниками цього методу $є$ значна кількість науковців, таких як Ф.Фолоні [11], К. Ших [12], М. Нхуман [13], О. Білетський [14], В. Бевз [15] та багато інших. Тут необхідно підкреслити, що індикаторний підхід акцентує увагу на опосередкованих аспектах людського капіталу і не намагається виміряти людський капітал безпосередньо. На відміну від двох інших підходів, індикативний підхід заснований на декількох показниках, які, хоча більш інформативні, не мають загальної метрики, тому роблять цей метод менш релевантним для таких цілей, як оцінка 
«стійкості» шляху розвитку, який вимагає порівняння змін в сукупному запасу людського капіталу з запасами інших типів активів.

Наступний підхід (витратний підхід), що оцінює собівартість формування людського капіталу. Метод собівартості, розроблений Е. Енгелем у 1883 році, вперше оцінив людський капітал, ґрунтуючись на збільшенні витрат для своїх батьків. Е. Енгель вважав, що людина $€$ повністю сформованою до 26 років, тому витрати на виховання людини дорівнюватимуть сумі витрат, необхідних для його виховання з моменту зачаття до 25 років, якщо припустити, що витрати на виховання людини у віці $\mathrm{x}<26$, що належить і-му класу при народженні, то за своє життя людина повинна витратити більшу кількість коштів на своїх дітей, порівняно кількості коштів, яка була витрачена на неї. Однак, як показали подальші дослідження науковців К. Дарума та І. Слотті [0], ця модель не повинна розглядатися як оцінка людського капіталу, оскільки це просто підсумовування історичних витрат та ігнорування тимчасової вартості грошей, а також соціальних витрат, які вкладаються в людей.

Подальші дослідження процесів інтелектуалізації економіці пов'язані з такими вченими, як Г. Вітадінні [0], Д.Кендрік [4], А. Франк [5], П.Каталіздакіс [6], що були одними з основних прихильників систематичного вимірювання людського капіталу за допомогою підходу, заснованого на витратах. Так, зазначені автори у своїх дослідженнях розділяли інвестиції в людський капітал на матеріальні і нематеріальні, де матеріальний компонент складався 3 витрат, необхідних для фізичного виховання людини. Нематеріальні інвестиції, навпаки, спрямовані на підвищення якості або продуктивності праці, що включають витрати на охорону здоров'я і безпеку, мобільність, освіту, а також альтернативні витрати на учнів, які відвідують школу. Цей підхід давав оцінку ресурсів, вкладених в освіту та інші сектори, пов'язані з людським капіталом, які можуть бути корисні для аналізу витрат і вигод. Його також легко можна було застосовувати завдяки доступності даних про державні і приватні витрати. Разом з цим даний підхід не враховував той факт, що навіть, якщо витрати були значними, це не означало будь-якої віддачі від такої інвестиції. Оскільки немає ніякого взаємозв'язку між інвестиціями та якістю продукції, що випускається: вартість капіталу визначається попитом на нього, а не вартістю виробництва [06].

Іншим підходом щодо оцінки людського капіталу, який набув значної популярності у першій половині 1980-хx років був підрахунок 
доходів. Зазначений метод, акцентував увагу на вимірюванні людського капіталу шляхом підсумовування дисконтованих значень всіх майбутніх потоків доходів, які люди очікують заробити протягом життя. Серед науковців, які були прихильниками доходного підходу до визначення людського капіталу, слід виділити Н. Мілера [7], Б. Пората [8], М. Дахана [9], Д. Джоргенсона [10] та багатьох інших. На відміну від підходу, заснованого на витратах, який фокусувався на стороні введення, підхід, заснований доході, вимірював запас людського капіталу з боку випуску (хоча результат в цьому методі обмежений приватними грошовими вигодами, які отримує людина, в яку втілено людський капітал). Центральне припущення заснованого на доході підходу полягає в тому, що праця оплачується відповідно до його граничної продуктивності. Тобто чим більша заробітна плата, тим більша цінність робітника і тим більше грошей в нього було інвестовано. У більшості випадків застосування цього методу було досить складним, оскільки розрахунок вівся для особи в кожній категорії класифікації окремо (стать, вік та рівень освіти). Ключове припущення, що використовувалось, полягало в тому, що людина 3 даним віком, статтю та рівнем освіти буде мати такий же трудовий дохід, як і інші особи аналогічної категорії. Таким чином, застосування методу за доходами $€$ досить фрагментарним на сьогодні.

В контексті авторського дослідження окремо слід виділити методологію дослідження процесів інтелектуалізації від Всесвітнього Банку. Всесвітній банк міжурядова організація, що складається 3 189 країн-членів. Насамперед слід відзначити, що причина дослідження розвитку людського капіталу, що здійснюється командою Світового Банку, виражається у необхідності допомоги керівникам держав у створенні політичної платформи, яка забезпечить пріоритет інвестицій в охорону здоров'я, освіту та соціальний захист [1]. Завдання методології Світового Банку щодо дослідження процесів інтелектуалізації полягає в тому, щоб швидкими темпами просуватися по шляху побудови в світі суспільства, в якому всі діти могли б отримати в школі реальні знання i, ставши дорослими, могли б вийти на ринок праці здоровими, кваліфікованими та продуктивними працівниками. Також запровадження розрахунку індексу розвитку людського капіталу покликано за допомогою програми інформаційнопропагандистської та аналітичної роботи, підвищити обізнаність про важливість людського капіталу для нарощування його в країнахклієнтах. 
В цілому такий підхід допомагає країнам учасникам проєкту отримати уявлення про те, які заходи дають реальну віддачу і на що слід спрямовувати ресурси. Крім того, це підвищує обізнаність відповідальних осіб про значення інвестицій в людський капітал, створюючи імпульс для дій уряду. У глобальному масштабі всебічна оцінка дозволяє виявляти розриви між країнами і стимулювати попит на інвестиції в людей. Проєкт розвитку людського капіталу дозволяє посилити аналітичну та науково-дослідну роботу в напрямках, що сприяють інтелектуалізації економіки.

Наступною інституцією, яка розраховує аналогічний індекс, $є$ програма розвитку ООН (ПРООН), глобальна мережа, що фінансується виключно за рахунок добровільних внесків державчленів ООН. Організація працює в 177 країнах, де вона працює 3 місцевими органами влади для вирішення проблем розвитку місцевого потенціалу. Індекс людського розвитку (ІЛР) в межах зазначеної організації був створений для того, щоб підкреслити, що люди і їх можливості повинні бути кінцевими критеріями для оцінки розвитку країни, а не тільки економічного зростання.

Індекс розвитку людського потенціалу ПРООН досить схожий, але трохи відрізняється від Індексу людського капіталу за методологією Світового Банку. Хоча обидва індекси розміщують в центр уваги величезне значення людських здібностей для розвитку країни, Індекс людського капіталу більше акцентує увагу на економічній необхідності інвестицій в людей. Ці два індекси відмінно доповнюють один одного, але вони по-різному формуються. Індекс людського капіталу пов'язує окремі результати в області розвитку людського капіталу з рівнями продуктивності та доходів. Він являє собою прогнозний вимір впливу, як поточні результати в галузі охорони здоров'я та освіти (включаючи вимірювання тривалості шкільного навчання в прив'язці до рівня отриманих знань), впливатимуть на продуктивність наступного покоління працівників. На противагу індексу людського капіталу рівень життя в індексі людського розвитку вимірюється валовим національним доходом на душу населення. ІЛР використовує логарифм доходу, щоб відобразити важливість доходу як кінцевого показника. Головним недоліком цього індексу людського розвитку $є$ те, що він спрощує та відображає тільки частину того, що представляє за собою людський розвиток. Він не відображає нерівності, бідності, безпеки людини, розширення прав та можливостей населення [24].

Окрім міждержавних організацій, проблематикою дослідження процесів інтелектуалізації економіки займається Всесвітній 
економічний форум (ВЕФ) [20шибка! Источник ссылки не найден.] міжнародна організація державно-приватного співробітництва. Форум залучає провідних політичних, ділових, культурних та інших лідерів суспільства для формування глобальних, регіональних і галузевих програм. За своєю організаційною суттю Всесвітній економічний форум некомерційний фонд. Він незалежний, та не прив'язаний до будь-яких особливих інтересів, тому $\epsilon$ гарною альтернативою для міждержавних організацій, які можуть контролюватися 3 певних центрів сили. Ще однією характеристикою, яка робить зазначену організацію релевантною в контексті авторського дослідження, це методологія процесів інтелектуалізації економіки, що значно відрізняється від попередніх міжнародних організацій. Взагалі у своїй методології Міжнародний економічний форум сприймає всі показники як сукупність інститутів, які визначають рівень продуктивності країни. Рівень продуктивності, в свою чергу, визначає рівень процвітання, якого може досягти економіка, також визначає норми прибутку, одержувані від інвестицій в економіку, які $є$ основними факторами ії зростання.

В цьому контексті оцінюється ефективність і гнучкість ринку праці, прозорість відносин між роботодавцем i робітником, прозорість механізму розрахунку заробітної плати, якою мірою політика на ринку праці допомагає безробітним, як часто люди переїжджають в інші частини країни з професійних причин, якою мірою заробітна плата пов'язана з продуктивністю працівників, якою мірою розраховуються ставки податку на працю. Слід відзначити, що на відміну від інших методологія Всесвітнього економічного форуму охоплює значно більшу кількість аспектів інтелектуалізації економіки, єдиним недоліком такої методології $є$ експертна оцінка, за якою підраховуються підіндекси.

Отже, узагальнюючи наявні методології дослідження процесів інтелектуалізації в сучасній економіці було удосконалено підходи оцінки інтелектуального капіталу за рахунок обґрунтування меж застосування існуючих метрик. В межах систематизації наявних наукових опрацювань виявлено, що наявні наукові опрацювання щодо методології дослідження процесів інтелектуалізації в сучасній економіці слід розділяти на дві великі галузі знань. Це опрацювання, що стосуються процесів інтелектуальної власності як певного результату щодо наявності інтелектуальних ресурсів, та інша галузь знань, що має справу з людським капіталом, який $є$ основною для формування інновацій та розвитку. Ці дві галузі наукових концепцій досить погано пов'язані між собою, це добре простежується як у 
класичних, так і сучасних роботах з інтелектуалізації економіки. Міжнародні організації також розділяють ці категорії в своїх методологічних поглядах, однак погоджуються з тим, що людський капітал та інтелектуальна власність $€$ елементами однієї системи.

Висновки. Отже, новітні методології процесів інтелектуалізації в сучасній економіці хоча і містять достатньо велику кількість показників, проте вони мають досить фрагментарний характер. На противагу цьому, системні підходи мають міжнародні організації в сфері інтелектуальної власності та людського капіталу, оскільки саме міжнародні організації координують процеси в цій сфері. Однак методики, що використовують Всесвітня організація інтелектуальної власності (BOІB), Організація економічного співробітництва та розвитку (ОЕСР), Світова організація торгівлі (СОТ), Всесвітній Банк, Всесвітній економічний форум, також вирішують специфічні проблеми на міжнародному рівні і не можуть використовуватись на національному. В таких умовах подальше обґрунтування методології процесів інтелектуалізації в національній економіці має значний практичний інтерес.

1. Vittadini G., Lovaglio P. G. Evaluation of the Dagum-Slottje method to estimate household human capital (2007). Structural Change and Economic Dynamics. T. 18. № 2. C. 270-278. 2. Kendrick J.W. Total capital and economic growth (1994). Atlantic Economic Journal. T. 22. № 1. C. 1-18. 3. Frank A. G. Human capital and economic growth (1960). Economic Development and Cultural Change. T. 8. № 2. C. 170-173. 4. Kalaitzidakis $P$. et al. Measures of human capital and nonlinearities in economic growth (2001). Journal of Economic Growth. T. 6. № 3. C. 229-254. 5. Miller H. P. Lifetime income and economic growth (1965). The American Economic Review. T. 55. № 4. C. 834-844. 6. Ben-Porath Y. Lifetime Income and Economic Growth: Comment (1966). The American Economic Review. T. 56. № 4. C. 869-872. 7. Dahan M., Tsiddon D. Demographic transition, income distribution, and economic growth (1998). Journal of Economic growth. T. 3. № 1. C. 29-52. 8. Jorgenson D. W., Fraumeni B. M. Investment in education and US economic growth (1992). The Scandinavian Journal of Economics. C. 51-70. 9. Folloni G., Vittadini G. Human capital measurement: a survey (2010). Journal of economic surveys. T. 24. № 2. C. 248-279. 10. Shih K. H. et al. The indicators of human capital for financial institutions (2010). Expert Systems with Applications. T. 37. № 2. C. 1503-1509. 11. Nhuan M. T. et al. An indicator-based approach to quantifying the adaptive capacity of urban households: the case of Da Nang city, Central Vietnam (2016). Urban Climate. T. 15. С. 60-69. 12. Biletskiy 0. Індикативна моніторингова оцінка якості формування та використання людського капіталу в Україні (2016). Економіка i організація управління. № 2 (22). С. 239-246. 13. Бевз В. П., Бугаенко Є. О. Підвищення ефективності використання людського капіталу як визначений чинник економічного та соціального розвитку (2012). Формування ринкових відносин в Україні. № 5. С. 133-139. 14. Guide on Measuring Human Capital.

URL: https://www.unece.org/fileadmin/DAM/stats/documents/ece/ces/bur/2016/February /15-Add1-Human_Capital_Guide_after.pdf. (Accessed: 22.05.2020). 15. Inside WIPO. 
URL: https://www.wipo.int/about-wipo/en/ (Accessed: 22.05.2020). 16. Organisation for Economic Co-operation and Development. URL: https://www.oecd.org/about. (Accessed: 22.05.2020). 17. World Trade Organization. URL: https://www.wto.org/ (Accessed: 22.05.2020). 18. Nauenberg E., Basu K., Chand H. Hirschman-Herfindahl index determination under incomplete information (1997). Applied Economics Letters. T. 4. № 10. C. 639-642. 19. Schmidt A., Walter S. G., Walter A. Radicalness of technological inventions and young venture performance. The role of technological competition and product diversity (2013). IEEE Transactions on Engineering Management. T. 60. № 4. C. 728-738. 20. Measuring the technological and economic value of patents. URL: https://www.oecd.org/sti/ieconomy/Chapter2-KBC2-IP.pdf (Accessed: 22.05.2020). 21. United Nations Development Programme. URL: http://hdr.undp.org/en/content/human-development-index-hdi (Accessed: 22.05.2020).

\section{REFERENCE:}

1. Vittadini G., Lovaglio P. G. Evaluation of the Dagum-Slottje method to estimate household human capital (2007). Structural Change and Economic Dynamics. T. 18. № 2. S. 270-278. 2. Kendrick J. W. Total capital and economic growth (1994). Atlantic Economic Journal. T. 22. № 1. S. 1-18. 3. Frank A. G. Human capital and economic growth (1960). Economic Development and Cultural Change. T. 8. № 2. S. 170-173. 4. Kalaitzidakis $P$. et al. Measures of human capital and nonlinearities in economic growth (2001). Journal of Economic Growth. T. 6. № 3. S. 229-254. 5. Miller H. P. Lifetime income and economic growth (1965). The American Economic Review. T. 55. № 4. S. 834-844. 6. Ben-Porath Y. Lifetime Income and Economic Growth: Comment (1966). The American Economic Review. T. 56. № 4. S. 869-872. 7. Dahan M., Tsiddon D. Demographic transition, income distribution, and economic growth (1998). Journal of Economic growth. T. 3. № 1. S. 29-52. 8. Jorgenson D. W., Fraumeni B. M. Investment in education and US economic growth (1992). The Scandinavian Journal of Economics. S. 51-70. 9. Folloni G., Vittadini G. Human capital measurement: a survey (2010). Journal of economic surveys. T. 24. № 2. S. 248-279. 10. Shih K. H. et al. The indicators of human capital for financial institutions (2010). Expert Systems with Applications. T. 37. № 2. S. 1503-1509. 11. Nhuan M. T. et al. An indicator-based approach to quantifying the adaptive capacity of urban households: the case of Da Nang city, Central Vietnam (2016). Urban Climate. T. 15. S. 60-69. 12. Biletskiy 0. Indykatyvna monitorynhova otsinka yakosti formuvannia ta vykorystannia liudskoho kapitalu $v$ Ukraini (2016). Ekonomika i orhanizatsiia upravlinnia. № 2 (22). S. 239-246. 13. Bevz V. P., Buhaenko Ye. 0. Pidvyshchennia efektyvnosti vykorystannia liudskoho kapitalu yak vyznachenyi chynnyk ekonomichnoho ta sotsialnoho rozvytku (2012). Formuvannia rynkovykh vidnosyn v Ukraini. № 5. S. 133-139. 14. Guide on Measuring Human Capital. URL: https://www.unece.org/fileadmin/DAM/stats/documents/ece/ces/bur/2016/February /15-Add1-Human_Capital_Guide_after.pdf. (Accessed: 22.05.2020). 15. Inside WIPO. URL: https://www.wipo.int/about-wipo/en/ (Accessed: 22.05.2020). 16. Organisation for Economic Co-operation and Development. URL: https://www.oecd.org/about. (Accessed: 22.05.2020). 17. World Trade Organization. URL: https://www.wto.org/ (Accessed: 22.05.2020). 18. Nauenberg E., Basu K., Chand H. Hirschman-Herfindahl index determination under incomplete information (1997). Applied Economics Letters. T. 4. № 10. S. 639-642. 19. Schmidt A., Walter S. G., Walter A. Radicalness of technological inventions and young venture performance. The role of technological 
competition and product diversity (2013). IEEE Transactions on Engineering Management. T. 60. № 4. S. 728-738. 20. Measuring the technological and economic value of patents. URL: https://www.oecd.org/sti/ieconomy/Chapter2-KBC2-IP.pdf (Accessed: 22.05.2020). 21. United Nations Development Programme. URL: http://hdr.undp.org/en/content/human-development-index-hdi

(Accessed: 22.05.2020).

Sazonets O. M. [1; ORCID ID: 0000-0001-6521-7815], Doctor of Economics, Professor

Nykonchuk V. M. [2; ORCID ID: 0000-0003-4425-4283], Candidate of Economics (Ph.D.)

${ }^{1}$ National University of Water and Environmental Engineering, Rivne ${ }^{2}$ Private Higher Education Establishment «Academician Stepan Demianchuk International University of Economics and Humanities», Rivne

\section{RESEARCH METHODOLOGY OF INTELLECTUALIZATION PROCESSES IN MODERN ECONOMY}

The methodological bases of intellectual capital research are substantiated in the article.

It is proposed to consider the methodology of research of intellectualization processes in modern economy as the process of intellectual property, as a certain result in terms of the availability of intellectual resources; human capital, which is fundamental for the formation of innovation and development.

The authors conducted a comparative analysis of approaches to the assessment of human capital. Based on the research data, it is determined that among the available approaches that assess human capital today are: cost approach, income approach and indicative approach.

The directions of intellectualization in the modern economy are determined. The methods used by the World Intellectual Property Organization (WIPO), the Organization for Economic Cooperation and Development (OECD), the World Trade Organization (WTO), the World Bank, and the World Economic Forum are described. Indicators for assessing the effectiveness of the national institutional system for ensuring the quality of education and competitiveness of science using basic indicators as the main source of information are proposed. Therefore, the latest methodologies of intellectualization processes in the modern economy, although they contain a large number of indicators, but they are quite fragmentary.

Summarizing the existing methodologies for the study of intellectualization processes in the modern economy, it was proposed to improve approaches to assessing intellectual capital by justifying the limits of application of existing metrics. As part of the systematization of existing 
scientific studies, existing scientific studies on the methodology of studying the processes of intellectualization in the modern economy should be divided into two major areas of knowledge, these studies relate to the processes of intellectual property capital, which is fundamental for the formation of innovation and development.

In such conditions, further substantiation of the methodology of intellectualization processes in the national economy is of considerable practical interest.

Keywords: research methodology; human capital; intellectual property; institutionalization; basic indicators.

Сазонец О. Н. ${ }^{[1 ;}$ ORCID ID: 0000-0001-6521-7815],

д.э.н., профессор

Никончук В. М. [2; ORCID ID: 0000-0003-4425-4283],

К.Э.Н.

${ }^{1}$ Национальный университет водного хозяйства и природопользования, г. Ровно

2Частное высшее учебное заведение «Международный экономико-гуманитарный университет имени академика Степана Демьянчука», г. Ровно

\section{МЕТОДОЛОГИЯ ИССЛЕДОВАНИЯ ПРОЦЕССОВ ИНТЕЛЛЕКТУАЛИЗАЦИИ В СОВРЕМЕННОЙ ЭКОНОМИКЕ}

В статье обоснованы методологические основы исследования интеллектуального капитала.

Предлагается рассматривать методологию исследования процессов интеллектуализации в современной экономике как процесс интеллектуальной собственности, как определенный результат с точки зрения доступности интеллектуальных ресурсов; человеческий капитал, который имеет фундаментальное значение для формирования инноваций и развития.

Авторами проведен сравнительный анализ подходов к оценке человеческого капитала. На основе данных исследования определено, что среди имеющихся подходов, которые оценивают человеческий капитал сегодня можно выделить: подход по затратам, подход по доходам и индикативный подход.

Определены направления интеллектуализации в современной экономике. Описаны методики, использующие Всемирная организация интеллектуальной собственности (ВОИС), Организация экономического сотрудничества и развития (ОЭСР), Всемирная торговая организация (ВТО), Всемирный Банк, Всемирный экономический форум. Предложены показатели оценки эффективности национальной институциональной системы обеспечения качества образования и конкурентоспособности 
науки с использованием базовых индикаторов как основного источника информации. Поэтому новейшие методики интеллектуализации процессов в современной экономике хоть и содержат большое количество показателей, но достаточно фрагментарны.

Обобщая имеющиеся методологии исследования процессов интеллектуализации в современной экономике, было предложено усовершенствовать подходы оценки интеллектуального капитала за счет обоснования границ применения существующих метрик. В рамках систематизации существующих научных исследований существующие научные исследования по методологии изучения процессов интеллектуализации в современной экономике следует разделить на две основные области знаний, эти исследования относятся к процессам интеллектуального капитала, что является фундаментальным для формирования инноваций и развития.

В таких условиях дальнейшее обоснование методологии процессов интеллектуализации в национальной экономике имеет значительный практический интерес.

Ключевые слова: методология научных исследований; человеческий капитал; интеллектуальная собственность; институализация; базовые индикаторы. 